\title{
COMUNICACÕES
}

\section{Occurrence of Ralstonia solanacearum on olive tree in Brazil}

\author{
Nilvanira Donizete Tebaldi ${ }^{1}$, Luciano Nunes Leite ${ }^{1,2}$, Janaína Marianno de Marque ${ }^{2}$, Mayara Cristina Aliandro \\ Furlanetto $^{2}$, Lara Caroline Borges Moreira Mota ${ }^{1}$
}

${ }^{1}$ Instituto de Ciências Agrárias, Universidade Federal de Uberlândia, Av. Amazonas s/n, Bloco 4C-127, Campus Umuarama, CEP 38.400-902, Uberlândia, MG, Brazil; ${ }^{2}$ Laboratório Atena, Rua dos Faveiros, 260, CEP 12.945-490, Atibaia, SP, Brazil

Autor para correspondência: Nilvanira Donizete Tebaldi (nilvanira@iciag.ufu.br)

Data de chegada: 01/04/2014. Aceito para publicação em: 15/04/2014.

$10.1590 / 0100-5405 / 1983$

Bacterial wilt, caused by Ralstonia solanacearum (Smith) Yabuuchi et al. 1996, has been described for many crop plants in Brazil (MALAVOTA JR. et al. Phytopathologica Summa, v.34, s.suppl., 2008).

In 2011, olive trees (Olea europaea L.) in a field in Camanducaia, Minas Gerais State, Brazil, showed symptoms of permanent leaf wilting, stem rot, phelloderm loss near the ground and vascular tissue discoloration (Figure 1). Bacterial exudation from infected tissue was observed under the microscope; then, the pathogen was isolated on nutrient-agar. Bacterial identification was done and the following characteristics were evidenced: irregular colonies that were white, smooth, flowing, opaque on 523-medium after 2-3 days at $28{ }^{\circ} \mathrm{C}$, including dissemination of brown pigment, and Gramnegative; oxidation/fermentation: strictly aerobic, colonies showing reddish center and white edges on Kelman-medium, oxidasepositive, catalase-positive, biovar 1 (maltose, lactose, cellobiose, mannitol, sorbitol and dulcitol-negative), growth at $37{ }^{\circ} \mathrm{C}$, gelatin liquefaction-negative, starch hydrolysis-negative, esculinnegative, arginine-positive, motility-positive and hypersensitivity reaction-positive on tobacco (SCHAAD et al. Laboratory guide for identification of plant pathogenic bacteria. APS St. Paul, 2001). For the pathogenicity test, three olive plants of Arbequina variety (approximately 1 year old) were inoculated, by using a needle and a syringe, with a bacterial suspension at $10^{9} \mathrm{CFU} \cdot \mathrm{mL}^{-1}\left(\mathrm{OD}_{550}=0.5\right)$. Control olive plants were inoculated with saline solution at $0.85 \%$. The plants were maintained in a moist chamber for $24 \mathrm{~h}$ before and after inoculation under greenhouse condition. After 12 days, the observed symptoms were wilt and dry leaves, from which the bacteria were reisolated. No symptoms were noted for control olive plants. Based on those characteristics, the bacterium was identified as Ralstonia solanacearum, the causal agent of olive bacterial wilt. This bacterium has been described for olive trees in Australia and China (Hall et al. 2012; He, 1986). However, this is the first report of Ralstonia solanacearum causing bacterial wilt on olive trees in Brazil. The strain was deposited in the phytopathogenic bacteria collection of the Institute of Agrarian Sciences of Uberlândia Federal University and codified as UFUC45.
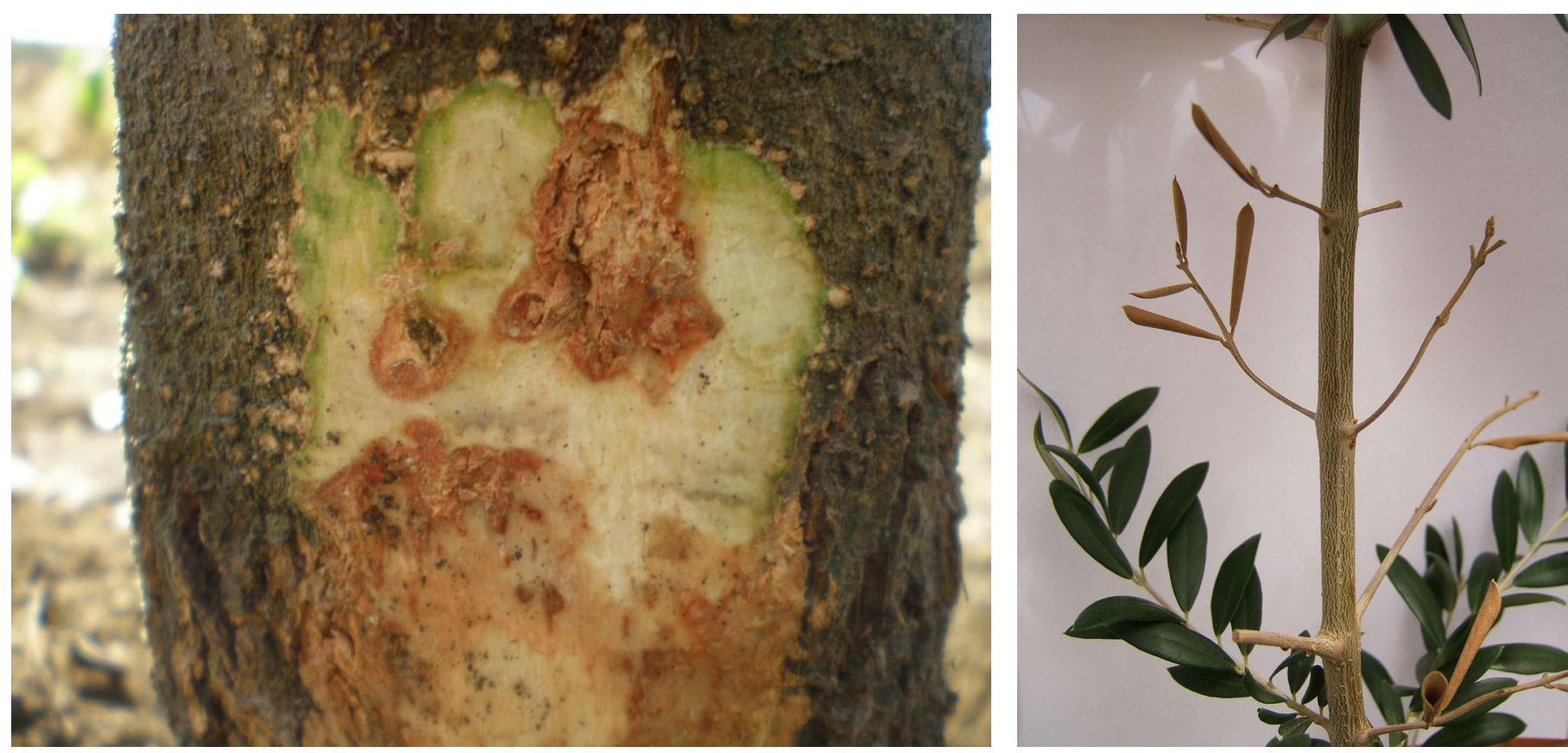

Figure 1. Symptoms of vascular tissue discoloration and leaf wilting on an olive plant, caused by Ralstonia solanacearum. 